\title{
Histological evaluation of the periodontal ligament from aged wistar rats supplemented with ascorbic acid
}

\author{
JACQUELINE N. ZANONI ${ }^{1}$, NATHALIA M. LUCAS ${ }^{2}$, ALINE R. TREVIZAN ${ }^{1}$ and IVAN D.S. SOUZA ${ }^{1}$ \\ ${ }^{1}$ Departamento de Ciências Morfológicas, Universidade Estadual de Maringá, \\ Avenida Colombo, 5790, 87020-900 Maringá, PR, Brasil \\ ${ }^{2}$ Departamento de Odontologia, Universidade Estadual de Maringá, \\ Avenida Colombo, 5790, 87020-900 Maringá, PR, Brasil
}

Manuscript received on March 22, 2012; accepted for publication on August 1, 2012

\begin{abstract}
Ascorbic acid (AA) is able to neutralize reactive oxygen species and is essential for collagen synthesis. In aging process oxidative stress is elevated. This study aims to investigate the effects of AA supplementation on the periodontal ligament (PL) of rats during aging. Twenty five rats were used and divided into groups: J90 (90-dayold control), E345 (345-day-old control), E428 (428-day-old control), EA345 (345-day-old supplemented with AA from 90-day-old on) and EA428 (428-day-old supplemented with AA from 90-day-old on). We analyzed the thickness, density of fibroblasts and blood vessels and collagen fibers types in the PL. In group J90 there was predominantly type III collagen fibers $(87.64 \%)$. In animals supplemented with AA, the area filled by type I fibers (group EA345: 65.67\%, group EA428: 52.23\%) was higher than type III fibers. PL in group EA428 was thicker than the one observed in group E428 $(P<0.05)$. During natural aging process, AA promoted the maturation of collagen fibers and enhanced angiogenesis in periodontal ligament. One can conclude that the supplementation with AA represented a beneficial factor for the development of PL in aged rats.
\end{abstract}

Key words: aging, ascorbic acid, collagen, periodontal ligament.

\section{INTRODUCTION}

The periodontal ligament (PL) is a loose connective tissue, richly enervated and vascularized, nonmineralized, with important peculiar localization and functionality in periodontium. PL is crossed throughout its extension by thick bundles of collagen fibers that insert either in the cementum or in the alveolar process (Katchburian and Arana 2004). PL is responsible by shock absorption and proprioceptive sensorial perception, aiming a comfortable adjust of dental arches during chewing (Lindhe and Karring 2003).

Correspondence to: Jacqueline Nelisis Zanoni

E-mail:jnzanoni@uem.br
In molar teeth of rats, periodontal ligament is normally constituted by $35 \%$ of fibroblastic cells and $51 \%$ in dry weight of their secretion product, the collagen fibers (Guilherme 2006). Collagen in PL is a mixture of types I (the most abundant) and III (Katchburian and Arana 2004, Freeman 2001). They are disposed in bundles of fibers that resemble a braid rope (Freeman 2001). According to Berkovitz et al. (2003), collagen fibers represent $90 \%$ of the total fibers and collagens type I and III correspond to $70 \%$ and $20 \%$ of these fibers, respectively. Other types of collagen found in small proportion are IV, V, VI, VII and XII, from 
these, types IV and VII are associated to vessels and epithelial cells (Berkovitz et al. 2003). Beyond collagen fibers, one can find oxytalan and elastic fibers, depending on the species.

Fibroblasts are responsible for the regeneration of teeth support structures. Furthermore, they play an essential role in teeth adaptability towards mechanical loads (Van Der Pauw et al. 2001), promoted by chewing or orthodontic movements (Reichenberg et al. 2005). They are arranged along the axes of the bundles of fibers and emit citoplasmic processes that involve them. This cell presents a welldeveloped cytoskeleton that assures its migration during repair of periodontal ligament (Katchburian and Arana 2004, Freeman 2001). Other cells that are considered part of PL are the cementoblasts and osteoblasts that present synthetic activity and are originated from ectomesenchymal cells (Lindhe and Karring 2003). It can also be found cementoclasts and osteoclasts, responsible for reabsorption and originated from precursors in bone marrow. Finally, there are also the epithelial cells or cell rests of Malassez (Berkovitz et al. 2003).

During aging, collagen in PL is susceptible to damages once its synthesis may be altered due to the lack of ascorbic acid (AA), which presents reduced plasmatic levels as a consequence of the elevated oxidative stress among other factors (Russell and Suter 1993, Li and Schellhorn 2007). The nocive effects of free radicals are one of the causes of cell aging (Azulay et al. 2003). However, human organism is protected from these radicals by the action of antioxidants that may be endogenous and/ or exogenous. AA is the most abundant antioxidant in human organism (Azulay et al. 2003, Wilson 2002) and in spite of indispensable to metabolism, it cannot be synthesized by humans or guinea pigs (Li and Schellhorn 2007, Azulay et al. 2003, Jacobs and Wood 2003, Tuero 2000). This deficiency is caused by the absence of the hepatic enzyme L-gulonolactone oxidase, which is responsible for AA biosynthesis from glucose ( $\mathrm{Li}$ and Schellhorn
2007, Azulay et al. 2003, Wilson 2002, Tuero 2000).

In addition to its antioxidant capacity, AA plays important roles in human physiology, such as the synthesis of collagen fibers ( $\mathrm{Li}$ and Schellhorn 2007, Azulay et al. 2003, Padh 1991, Tuero 2000, Rowe et al. 1999, Aranha et al. 2000, Clark et al. 2002). This vitamin is a cofactor for two enzymes, lysyl and prolyl hydroxylases, which are related to collagen hydroxylation. The function of AA as a cofactor for these enzymes is to avoid their iron atom oxidation and, consequently, protect them from autoinactivation (Azulay et al. 2003, Tuero 2000, Parsons et al. 2006, Murad et al. 1981, Tsuchiya and Bates 1998, Senturk et al. 2004). AA also enhances the collagen synthesis because it increases the gene expression of fibroblasts (Tuero 2000, Senturk et al. 2004).

Although the role of AA is well established, we did not find studies in the literature that report on the AA supplementation for a long time and aging. Considering this, it is speculated that the increase in oxidative stress, due to aging process, reduces the plasmatic levels of AA, what may impair collagen synthesis in PLof Wistar rats. In this way, the objective of this work is to analyze thickness, types of collagen fibers, density of fibroblasts and vascularization of PL of aging rats supplemented with AA.

\section{MATERIALS AND METHODS}

ANIMALS

In this study, were used 25 male Wistar rats (Rattus norvegicus) from the CentralVivariumofUniversidade Estadual de Maringá, Brazil. All experimental procedures are in accordance with the guidelines of the Colégio Brasileiro de Experimentação Animal (COBEA, Brazil) and approved by the Committee of Ethics in Animal Experimentation of Universidade Estadual de Maringá.

Animals were divided in five groups: J90: 90-day-old young rats; E345: 345-day-old aged rats; E428: 428-day-old aged rats; EA345: 345-day- 
old aged rats treated with AA since 90-day-old; and EA428: 428-day-old aged rats treated with AA since 90-day-old. During the experimental period, rats were kept in polypropylene boxes under controlled lighting (12 h light/dark) and temperature $\left(24 \pm 2^{\circ} \mathrm{C}\right)$. AA was dispensed in water at $1 \mathrm{~g} / \mathrm{L}$, daily (Young et al. 1992). Water intake was measured one week per month.

\section{MATERIAL PREPARATION}

Group J90 were weighted, anesthetized intraperitoneally with thiopental $(40 \mathrm{mg} / \mathrm{kg}$ of body weight) and killed at 90-day-old. After 255 days (for groups E345 and EA345) or 338 days (for groups E428 and EA428) of experiment, the other animals were killed using the same protocol. Jaws were removed, dissected, fixed in formaldehyde at $10 \%$ for 24 hours and stored in alcohol at $70 \%$. Jaws were decalcified in nitric acid at 5\% during seven days and then submitted to histological routine.

\section{ANALYSis OF PERIODONTAL LigAMENT THICKNESS}

Seven $\mu \mathrm{m}$-thick semi serial longitudinal sections of the incisor teeth roots were stained with hematoxylin and eosin (HE). The thickness of the $\mathrm{PL}$ in each animal was analyzed in six histological sections in cervical, middle and apical thirds of the roots. It was performed a total of 30 measures in each region. Measures were obtained through Olympus light microscope equipped with a Zeiss ocular micrometer at 40X magnification.

\section{ANALysis of Collagen Fibers IN THE MiddLe THIRD} OF THE ROOT

These slides were stained with picro-sirius and hematoxylin and analyzed under light microscope with a polarization filter. In this procedure, type I collagen fibers stained in yellow, orange or red and type III fibers stained in green.

For each histological section, 3 field-images from the middle third of the root were captured, at 40x magnification, summing 15 images and a total area of $0.302 \mathrm{~mm}^{2} /$ animal. All images were captured following the same illumination conditions, in the same day, by the same analyst. Then, images were analyzed with the aid of an image analysis software (Image Pro Plus 4.5) in order to determine the area occupied by type I, type III and total collagen fibers in each group.

\section{ANALYSIS OF DENSITY OF FIBROBLASTS}

This analysis used the same slides as in the determination of periodontal ligament thickness. Quantification was performed in cervical, middle and apical thirds of PL in the mesial face of tooth root. Five histological sections per animal were used to quantify all the fibroblasts present in five random microscopic fields, in each region, at 100x magnification. The total area analyzed in each region of PL of the root was $0.25 \mathrm{~mm}^{2} /$ animal.

\section{ANALYSIS OF DENSITY OF BloOd Vessels}

This analysis was performed simultaneously with the density of fibroblasts. In the same microscopic fields, blood vessels present in cervical, middle and apical thirds of PL in the mesial face of tooth root were quantified. Five histological sections per animal were used to quantify all the blood vessels present in five random microscopic fields, in each region, at 100x magnification. The total area analyzed in each region of PL of the root was 0.25 $\mathrm{mm}^{2} /$ animal.

\section{STATISTICAL ANALYSIS}

Data were statistically analyzed using Statistica and GraphPad Prism, and results were expressed as mean \pm standard error. For collagen fibers, morphometric data were set in delineation blocks followed by Tukey's test. For all the other data, it was applied one-way analysis of variance (ANOVA) followed by Tukey's test. Values of $P<0.05$ were considered statistically significant. 


\section{RESULTS}

No differences were observed when comparing the initial body weight among the groups studied $(P>$ $0.05)$. On the other hand, all the aged rats, treated or not with AA, presented an increased body weight $(P<0.05)$ when compared to young rats (Table I).

\section{TABLE I}

Initial and final body weight (g) of rats in groups: $\mathbf{J 9 0}$ (90-dayold young rats), E345 (345-day-old aged rats), EA345 (345-dayold aged rats treated with ascorbic acid since 90-day-old), E428 (428-day-old aged rats) and EA428 (428-day-old aged rats treated with ascorbic acid since 90 -day-old). $n=5$ rats per group.

\begin{tabular}{c|c|c|c|c|c}
\hline & J90 & $\mathbf{E 3 4 5}$ & EA345 & $\mathbf{E 4 2 8}$ & EA428 \\
\hline Initial & & 287.7 & 306.2 & 285.4 & 290.3 \\
weight & -- & \pm & \pm & \pm & \pm \\
& & 6.85 & 20.21 & 8.60 & 11.92 \\
\hline \multirow{2}{*}{ Final } & 357.6 & 445.6 & 470.9 & 501.6 & 446.7 \\
weight & \pm & \pm & \pm & \pm & \pm \\
& $9.80^{*}$ & 19.46 & 13.18 & 13.53 & 14.31 \\
\hline
\end{tabular}

$* P<0.05$ when compared to all the other groups in the same line.

The mean ingestion of AA during the experiment was of $39.98 \pm 1.456$ and $41.70 \pm 1.362$ $\mathrm{g} / \mathrm{L}$ for groups EA345 and EA428, respectively.

\section{ANALYSIS OF COLLAGEN FIBERS}

The mean total area occupied by collagen (types I and III) in PL for groups J90, E345, EA345, E428, EA428 was of $699.3 \mu \mathrm{m}^{2} ; 824 \mu \mathrm{m}^{2} ; 697.4 \mu \mathrm{m}^{2}$; $706.6 \mu \mathrm{m}^{2}$; $998.6 \mu \mathrm{m}^{2}$, respectively. In the group of young rats (J90), there was a higher proportion of type III collagen (Table II). In group E345, similar proportions of collagens type I and III were observed (Table II). On the other hand, group E428 presented a predominance of type III collagen in relation to type I (Table II). The treatment with AA in groups EA345 and EA428 promoted an increase in the proportion of type I collagen (Table II).

\section{THICKNESS OF PL}

Photomicrographies of periodontal ligament of all groups are showed in Figure 1. The mean thickness of PL, summing its three thirds, was of $290.37 \mu \mathrm{m}$,

\section{TABLE II}

Area occupied $\left(\mu \mathrm{m}^{2}\right)$ by the types I and III collagen and its proportion (\%) in the periodontal ligament of rats in groups: J90 (90-day-old young rats), E345 (345-day-old aged rats), EA345 (345-day-old aged rats treated with ascorbic acid since 90-day-old), E428 (428-day-old aged rats) and EA428 (428-dayold aged rats treated with ascorbic acid since 90-day-old). $\mathbf{n}=$ 5 rats per group.

\begin{tabular}{c|c|c|c|c}
\hline Groups & $\begin{array}{c}\text { Type I } \\
\text { collagen }\end{array}$ & $\begin{array}{c}\text { Proportion } \\
\text { of the area } \\
\text { occupied } \\
\text { by type I } \\
\text { collagen }\end{array}$ & $\begin{array}{c}\text { Type III } \\
\text { collagen }\end{array}$ & $\begin{array}{c}\text { Proportion } \\
\text { of the area } \\
\text { occupied by } \\
\text { type III } \\
\text { collagen }\end{array}$ \\
\hline $\mathbf{J 9 0}$ & $\begin{array}{c}86.4 \pm \\
21.24 *\end{array}$ & $12.36 \%$ & $\begin{array}{c}612.9 \pm \\
65.44 *\end{array}$ & $87.64 \%$ \\
\hline $\mathbf{E 3 4 5}$ & $\begin{array}{c}423.0 \pm \\
136.70^{* *}\end{array}$ & $51.33 \%$ & $\begin{array}{c}401.0 \pm \\
63.81 \#\end{array}$ & $48.67 \%$ \\
\hline $\mathbf{E A 3 4 5}$ & $\begin{array}{c}458.0 \pm \\
137.70\end{array}$ & $65.67 \%$ & $\begin{array}{c}239.4 \pm \\
28.15\end{array}$ & $34.33 \%$ \\
\hline $\mathbf{E 4 2 8}$ & $\begin{array}{c}272.8 \pm \\
62.12^{* * *}\end{array}$ & $38.61 \%$ & $433.8 \pm$ & $61.39 \%$ \\
\hline $\mathbf{E A 4 2 8}$ & $521.6 \pm$ & $52.23 \%$ & $477.0 \pm$ & $47.77 \%$ \\
\hline
\end{tabular}

* $P<0.05$ when compared to the other groups in the same column.

** $P<0.05$ when compared to group E428.

$* * * P<0.05$ when compared to group EA428.

$\# P<0.05$ when compared to group EA345.

$294.07 \mu \mathrm{m}, 271.30 \mu \mathrm{m}, 289.00 \mu \mathrm{m}, 332.60 \mu \mathrm{m}$ for groups J90, E345, EA345, E428, EA428 respectively $(\mathrm{P}>0.05$, when all groups were compared). In group EA428, PL was $20.11 \%$ (cervical third) and $19.50 \%$ (apical third), thicker when compared to group J90 $(P<0.05)$. In all groups studied, the thickness of PL was smaller in the middle third of the root in relation to the cervical and apical thirds (Figure 2).

AA supplementation in group EA428 resulted in a thicker PL (14.92\% in cervical third, $6.29 \%$ in middle third and $20.93 \%$ in apical third) when compared to group E428 $(P<0.05$, Figure 2$)$.

\section{DENSITY OF FIBROBLASTS}

In all groups studied, the density of fibroblasts was higher in the middle third of the root in relation to the cervical and apical thirds. A minor density of fibroblasts in the apical third was observed in group 

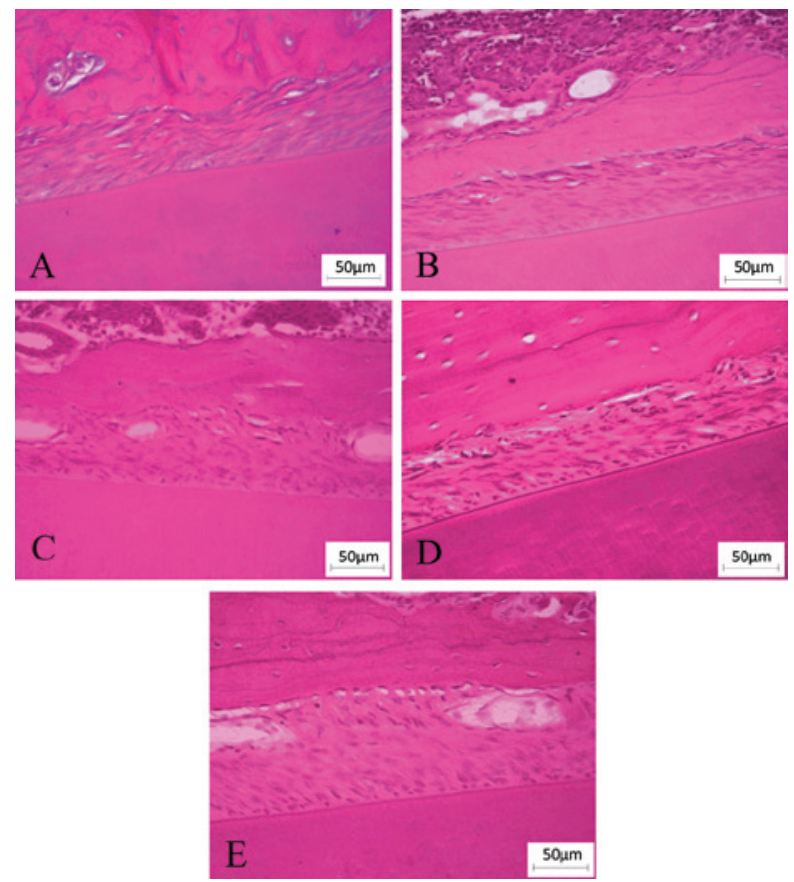

Figure 1 - Photomicrographies from random regions of the periodontal ligament of rats in groups: (A) J90 (90-day-old young rats), (B) E345 (345-day-old aged rats), (C) EA345 (345-day-old aged rats treated with ascorbic acid since 90-day-old), (D) E428 (428-day-old aged rats) and (E) EA428 (428-day-old aged rats treated with ascorbic acid since 90-day-old). Stained with hematoxylin and eosin. Calibration bar: $50 \mu \mathrm{m}$.

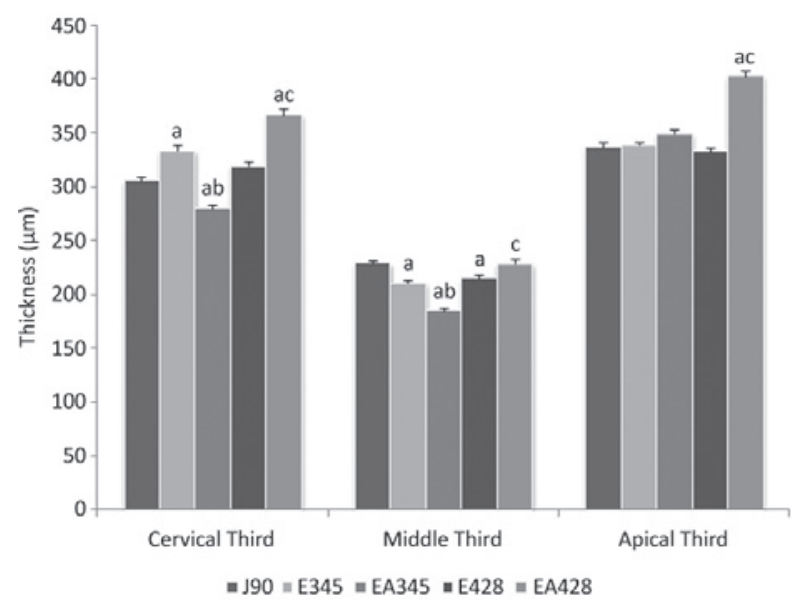

Figure 2 - Thickness of periodontal ligament $(\mu \mathrm{m})$ in cervical, middle and apical thirds of the root observed in groups: J90 (90-day-old young rats), E345 (345-day-old aged rats), EA345 (345-day-old aged rats treated with ascorbic acid since 90-day-old), E428 (428-day-old aged rats) and EA428 (428-day-old aged rats treated with ascorbic acid since 90 -day-old). $\mathrm{n}=5$ rats per group. a $P<0.05$ when compared to group J90, b $P<0.05$ when compared to group E345, c $P<0.05$ when compared to group E428.
J90 when compared to the other groups $(P<0.05$, Figure 3). In this study, AA supplementation and aging did not affected the total density of fibroblasts (summing of the density in the three thirds) among the groups studied $(P>0.05$, Table III).

\section{TABLE III}

Total density of fibroblasts and blood vessels in the periodontal ligament of rats in groups: $\mathbf{J 9 0}$ (90-day-old young rats), E345 (345-day-old aged rats), EA345 (345-day-old aged rats treated with ascorbic acid since 90-day-old), E428 (428-day-old aged rats) and EA428 (428-day-old aged rats treated with ascorbic acid since 90-day-old). $\mathbf{n}=\mathbf{5}$ rats per group.

\begin{tabular}{c|c|c|c|c|c}
\hline & J90 & E345 & EA345 & E428 & EA428 \\
\hline \multirow{2}{*}{ Fibroblasts } & $592.7 \pm$ & $587.0 \pm$ & $511.9 \pm$ & $364.3 \pm$ & $419.6 \pm$ \\
& 20.5 & 92.8 & 61.1 & 54.1 & 30.6 \\
& & & & & \\
Vessels & $144.1 \pm$ & $119.2 \pm$ & $126.0 \pm$ & $119.6 \pm$ & $173.0 \pm$ \\
& 9.9 & 12.4 & 11.0 & 15.4 & 20.7 \\
\hline
\end{tabular}

$P>0.05$ when all the groups were compared.

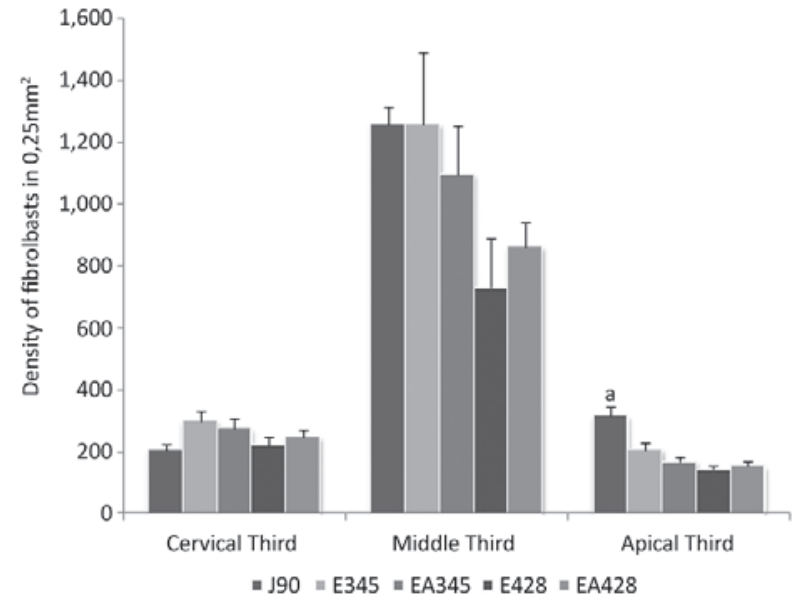

Figure 3 - Density of fibroblasts in cervical, middle and apical thirds of the root observed in groups: J90 (90-day-old young rats), E345 (345-day-old aged rats), EA345 (345-day-old aged rats treated with ascorbic acid since 90-day-old), E428 (428-day-old aged rats) and EA428 (428-day-old aged rats treated with ascorbic acid since 90-dayold). $\mathrm{n}=5$ rats per group. a $P<0.05$ when compared to the other groups.

\section{DENSITY OF BLOOD VESSELS}

In all groups studied, the density of vessels was higher in the middle third of the root in relation to the cervical and apical thirds. In the apical third, 
it was observed that aging promoted a reduction in the density of blood vessels, once group E428 presented a $38.46 \%$ smaller density of vessels when compared to group J90 ( $P<0.05$, Figure 4$)$. In the cervical third, groups EA345 and EA428 presented increases of $27.15 \%$ and $26.92 \%$ in the density of vessels in relation to groups E345 and E428, respectively ( $P>0.05$, Figure 4$)$. Yet in the cervical third, group EA428 presented a higher density of blood vessels than group E345 $(P<0.05$, Figure 4).

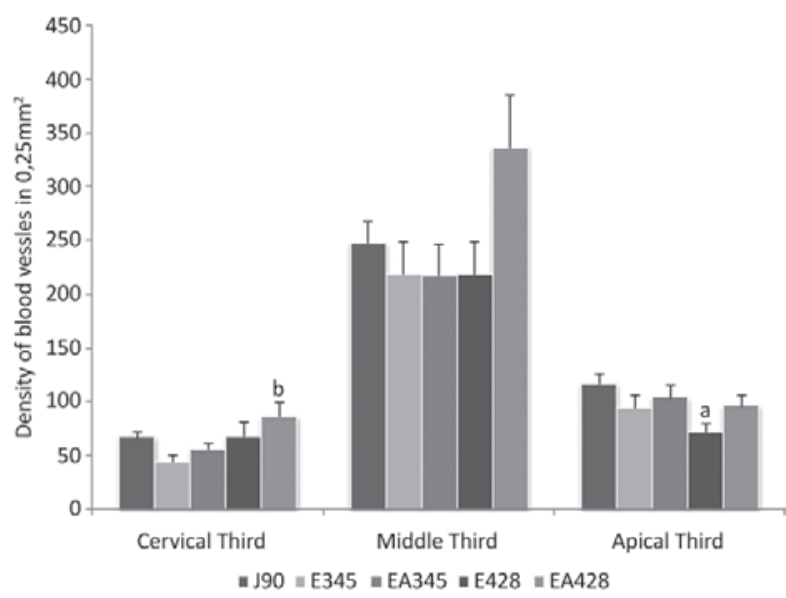

Figure 4 - Density of blood vessels in cervical, middle and apical thirds of the root observed in groups: J90 (90-day-old young rats), E345 (345-day-old aged rats), EA345 (345-day-old aged rats treated with ascorbic acid since 90-day-old), E428 (428-day-old aged rats) and EA428 (428-day-old aged rats treated with ascorbic acid since 90 -day-old). $\mathrm{n}=5$ rats per group. a $P<0.05$ when compared to group J90, b $P<0.05$ when compared to group E345.

No significant differences were observed when the total density of blood vessels was compared among all groups $(P>0.05$, Table III).

\section{DISCUSSION}

\section{ANIMAL PROCEDURES}

AA was used daily during 255 days in group EA345 and during 338 days in group EA428. This antioxidant was chosen for this experiment because it is important during aging, once there was an increase in the generation of free radicals and a decrease in antioxidant defenses, making tissues susceptible to the action of free radicals. Furthermore, it is a potent antioxidant, synthesized by rats but not by humans and guinea pigs (Azulay et al. 2003, Jacobs and Wood 2003, Tuero 2000). Another fundamental property of AA is the renewal of collagen fibers from periodontal ligament. In this way, AA deficiency may affect adversely the periodontal ligament. In some severe cases of scurvy, periodontal pathologies are developed, including edema, hemorrhage, collagen degeneration and bone tissue destruction (Glickman 1948).

It was observed that aging promoted an increase in body weight, similarly to the results found by Schoffen et al. (2005) who studied rats with 3 and 12 months. Those authors concluded that animal growth through aging was determining to this significant increase of weight. According to Phillips and Powley (2001), the weight of rats declines quickly only after 21 months-old. In this study, AA supplementation did not affected the gain of weight of the animals, once the final body weight of aged rats (E345 and E428) and treated aged rats (EA345 and EA428) were similar.

\section{TYPES OF COLLAGEN}

In group J90, there was a higher proportion of type III collagen. This predominance is probably related to the fact that this type of collagen is the first to be synthesized, considered as the young collagen. Later, this collagen is replaced by a mature collagen, the type I collagen. The fibrous architecture of PL reflects a biological adaptation to mechanical stimuli. The aggregation and organization of collagen are influenced by the duration and frequency of these stimuli onto the connective tissue (Komatsu et al. 2002).

In group E345, similar proportions of collagens type I and III were found. This result was probably due to a balance between the elaboration and degradation of the components of periodontal ligament at that age. So, there is a tendency to keep a normal structure, however, this balance may alter through aging, even if the fibroblast is in a high level of activity (Ferraris and Muñoz 2006). According to Komatsu et al. (2002), 
aged rats (24 months-old) presented a higher level of organization of their collagen fibers in the periodontal ligament when compared to young rats (2 months-old).

On the other hand, the higher proportion of type III collagen found in group E428 may be related to the low availability of AA with aging (Russell and Suter 1993). This vitamin is essential for the maintenance and stability of the type I collagen's structure and its absence probably leads to a reduction in that fiber proportion. This affirmative is supported by the fact that elders have reduced levels of AA and consequently proline residues are not hydroxylated, alpha-chains of tropocollagen are incapable to form stable helixes, and those helixes cannot form fibrils, affecting the structure and renovation of periodontal ligament (Azulay et al. 2003). Aging does not impair collagen deposition, however, delays tissue maturation (Biondo-Simões et al. 2005). According to the literature, type III collagen plays an important role in remodeling, as well as in normal growth and development of connective tissue (Duncan et al. 1984, Yen et al. 1989). It has been reported that the production of collagens type I and III is enhanced by AA, even though more intensely in the case of type I collagen (Azulay et al. 2003, Qiao et al. 2009).

ThICKNESS AND DENSITY OF FIBROBLASTS IN PL

This study demonstrated differences in the thickness of PL along the longitudinal axis of the tooth. In all groups studied, the middle third was narrower. These results were similar to those reported by Ferraris and Muñoz (2006) which described that PL is wider next to the cementumenamel junction and to the crown, whereas narrower in the middle of the root. Katchburian and Arana (2004) found that the thickness of PL varies according to the region of the root and generally decreases through aging.

The PL of group EA428 was thicker than that of group $\mathrm{J} 90(P<0.05$ in the cervical and apical thirds). This is probably due to the antioxidant effect of AA that allowed the organization of collagen fibers in bundles and kept them mature, avoiding their degradation. Furthermore, by comparing the results of group EA428 with those of the same age group (E428), it was verified a higher thickness in the three thirds of PL for the group treated with the vitamin $(P<0.05)$. The results suggest that AA influenced the organization of collagen fibers by structuring them as thicker and denser bundles (type I collagen) granting the teeth with more resistance to tensions.

In the apical third, it was observed a reduction in the density of fibroblasts through aging $(P<$ 0.05 ) and the supplementation with AA was not able to prevent this result. According to Phillips et al. (1994), aging causes a reduction in the proliferative capacity of fibroblasts and in the collagen synthesis, but supplementation with AA was able to enhance cell proliferation, as well as collagen synthesis in the dermic fibroblasts of elders. According to Matsuzaka et al. (2007), the cells in the PL of aged rats proliferated slower than in young rats. In the study of Goseki et al. (1996), the secretion of collagen was reduced through aging, once, at that stage, the catabolism in the cells of PL prevails over the anabolism. In this study, AA did not promoted the proliferation of fibroblasts since no significant differences were observed in their density. However, the vitamin was able to enhance the synthesis of collagen in group EA428 in comparison to young rats (J90). This result suggests that the alterations observed depend more on the functional capacity of the fibroblasts than on their proliferation.

\section{Density of Blood Vessels}

It was observed, in the apical third of PL, a reduction in the density of vessels in group E428 when compared to group J90. One can infer that aging process promoted an increase in the generation of free radicals and the endogenous AA was not able to supply all the needs of the cells.

$\mathrm{AA}$ is primordial in the angiogenesis process because it takes part in the synthesis of type IV collagen. When it lacks, the basal membrane of blood vessels is probably not properly formed. AA works 
as a cofactor for prolyl-hydroxylase by catalyzing the synthesis of hydroxyproline. Hydroxyproline is needed by endothelial cells to produce type IV collagen. According to Telang et al. (2007), the deposition of mature type IV collagen is essential to the formation of new vessels. The results obtained in the analysis of the density of blood vessels showed that the group treated with AA (EA428) presented higher density of vessels in relation to group E345, in the cervical third. This fact demonstrates that the supplementation with AA led to an increase in angiogenesis, as expected. Clinical manifestations of scurvy, such as gingival bleeding, hemorrhage and ecchymosis show the crucial importance of $\mathrm{AA}$ in the angiogenesis and in the repair of blood vessels (Telang et al. 2007).

Angiogenesis is responsible to keep hemostasis and to repair the PL after the treatment of chronic periodontal disease. During the Active Periodontal Therapy it is necessary that undifferentiated cells of the PL become differentiated to repair the tissue (Matsuzaka et al. 2007). The repair generally starts with the proliferation of vessels and cells but these events are impaired by aging process. So, it is suggested that the employment of AA during and after the Active Periodontal Therapy might be of great help, once, in this study, AA enabled the necessary stimuli to angiogenesis and to type I collagen formation, which bears the masticatory impulses more easily. In addition, there is the capacity of AA to enhance the immune response (Nishida et al. 2000, Parsons et al. 2006).

In the natural process of aging, AA worked as an enhancer for type I collagen formation and increased angiogenesis. One can conclude that AA supplementation was beneficial for the PL of aged rats.

\section{ACKNOWLEDGMENTS}

The authors would like to thank the technicians Mrs. Maria Euride do Carmo Cancino and Mrs. Maria dos Anjos Fortunato, from the Laboratory of Histology of the Universidade Estadual de Maringá, for their excellent technical support.

\section{RESUMO}

O ácido ascórbico (AA) neutraliza essas espécies reativas de oxigênio e é imprescindível para a síntese do colágeno. No processo de envelhecimento ocorre aumento do estresse oxidativo. Objetivamos investigar o efeito da suplementação com AA sobre o ligamento periodontal (LP) de ratos durante o processo de envelhecimento. Foram utilizados 25 ratos divididos em cinco grupos: J90 (90 dias de idade), E345 (345 dias de idade), E428 (428 dias de idade), EA345 (tratados com AA do $90^{\circ}$ ao $345^{\circ}$ dia) e EA428 (tratados com AA do $90^{\circ}$ ao $428^{\circ}$ dia). Foram analisadas espessura, densidade de fibroblastos e vasos sanguíneos, e o tipo de fibra colágena presente no LP. No grupo J90 houve um predomínio de fibras colágenas do tipo III $(87,64 \%)$. Nos animais suplementados com AA, a área ocupada pelas fibras tipo I (grupo EA345 - 65,67\%; grupo EA428 - 52,23\%) foi maior que aquelas do tipo III. A espessura do LP no grupo EA428 foi maior do que a observada no grupo E428 $(P<0,05)$. No processo de envelhecimento natural o AA atuou na maturação das fibras colágenas e estimulou a angiogênese no ligamento periodontal. Pode-se concluir que a suplementação com AA foi positiva para o LP de ratos envelhecidos.

Palavras-chave: envelhecimento, ácido ascórbico, colágeno, ligamento periodontal.

\section{REFERENCES}

ARANHA FQ, BARros ZF, MOURA LSA, GONÇALVES MCR, BARRoS JC, METRI JC AND SOUZA MS. 2000. The role of vitamin $\mathrm{C}$ in organic changes in aged people. Rev Nutr 13: 89-97.

AZULAy MM, LACERda CAM, PEREZ MA, FILGUEIRA AL AND Cuzzi T. 2003. Vitamin C. An Bras Dermatol 78: 265-274.

Berkovitz BKB, Holland GR AND MOXHAM BJ. 2003. Periodontal Ligament. In: BERKOVITZ BKB, HOLLAND GR AND MOXHAM BJ, Oral anatomy, histology and embryology, $3^{\text {rd }}$ ed., Philadelphia: Mosby, p. 180-204.

Biondo-Simões MLP, WeStPHAL VL, PAULA JB, Borsato KS AND NorOnHA L. 2005. Collagen synthesis after the implantation of polypropylene nets in the abdominal wall of young and old rats. Acta Cir Bras 20: 300-304.

Clark AG, Rohrbaugh AL, Otterness J and Kraus VB. 2002. The effects of ascorbic acid on cartilage metabolism in guinea pig articular cartilage explants. Matrix Biol 21: 175-184. 
Duncan GW, Yen EHK, Pritchard ET AND Suga DM. 1984. Collagen and prostaglandin synthesis in force-stressed periodontal ligament in vitro. J Den Res 63: 665-669.

FERRARIS MEG AND MUÑOZ AC. 2006. Inserction periodontium: cement, periodontal ligament and alveolar bone. In: FERRARIS MEG and MUÑOZ AC, Bucodental histology and embryology, $2^{\text {nd }}$ ed., Rio de Janeiro: Guanabara Koogan, p. 308-346.

FreEman E. 2001. Periodontium. In: TEN CATE AR, Oral Histology: development, structure and function, $5^{\text {th }}$ ed., Rio de Janeiro: Guanabara Koogan, p. 238-271.

GLICKMAN I. 1948. Acute vitamin C deficiency and periodontal disease. The periodontal tissues of the guinea pig in acute vitamin C deficiency. J Dent Res 27: 9-23.

Goseki T, SHIMIZU N, IwASAwAA T, TAKIGUCHIB H AND АВІКОВ Y. 1996. Effects of in vitro cellular aging on alkaline phosphatase, cathepsin activities and collagen secretion of human periodontal ligament derived cells. Mech Aging Dev 91: 171-183.

GuILHERME AJV. 2006. Histological evaluation of the periodontal ligament of Wistar rats under the effect of acute hipotireoidism inducted by metimazol $\left(\operatorname{tapazol}^{\mathbb{R}}\right)$. Faculdade de Ciências Médicas da Universidade Estadual de Campinas, p. 26-27.

JACOBS P AND WoOd L. 2003. Vitamin C. Dis Mon 49: 685-690.

KATCHBURIAN E AND ARANA V. 2004. Periodontium. In: KATCHBURIAN E AND ARANA V, Oral Histology and Embriology, $2^{\text {nd }}$ ed., Rio de Janeiro: Guanabara Koogan, p. 275-326.

Komatsu K, Mosekilde L, ViIdiK A and Chiba M. 2002. Polarized Light Microscopic Analyses of Collagen Fibers in the Rat Incisor Periodontal Ligament in Relation to Areas, Regions, and Ages. Anat Rec 268: 381-387.

LI Y AND SCHELlHORN HE. 2007. New Developments and Novel Therapeutic Perspectives for Vitamin C. J Nutr 137: 2171-2184.

LindHE J AND KARRING T. 2003. Anatomy of Periodontium In: LINDHE J, Clinical Periodontology and Implant Dentistry, $4^{\text {th }}$ ed., Rio de Janeiro: Guanabara Koogan, p. 3-42.

MATSUZAKA K ET AL. 2007. Age-related Differences in Expression of Vascular Endothelial Growth Factor by Periodontal Ligament Cells in vitro. Bull Tokyo Dent Coll 48: 143-146.

Murad S, Grove D, LindBerg KA, REYNOLdS G, SivarajaH A AND PINNELL SR. 1981. Regulation of collagen synthesis by ascorbic acid. Proc Natl Acad Sci 78: 2879-2882.

Nishida M, GRossi SG, DUNFORD RG, Ho AW, TREVISAN M AND GENCO RJ. 2000. Dietary Vitamin C and the Risk for Periodontal Disease. J Periodontol 71: 1215-1223.

PADH H. 1991. Vitamin C: never insights into its biochemical functions. Nutr Rev 49: 65-70.

Parsons KK, MaEda N, YAMAUChI M, BANES AJ AND KOLLER BH. 2006. Ascorbic acid-independent synthesis of collagen in mice. Am J Physiol Endocrinol Metab 290: 1131-1139.
Phillips CL, COMBS SB AND PINNELl SR. 1994. Effects of ascorbic acid on proliferation and collagen synthesis in relation to the donor age of human dermal fibroblasts. J Invest Dermatol 103: 228-232.

PHILliPS RJ AND POWLEY TL. 2001. As the gut ages: timetables for aging of innervation vary by organ in the Fisher 344 rat. J Comp Neurol 434: 358-377.

Qiao H, Bell J, Juliao S, Li L AND May JM. 2009. Ascorbic Acid Uptake and Regulation of Type I Collagen Synthesis in Cultured Vascular Smooth Muscle Cells. J Vasc Res 46: 15-24.

Reichenberg E, Redlich M, CANCEMI P, ZaKs B, Pitaru S, Fontana S, Pucci-Minafra I AND PALMON A. 2005. Proteomic analysis of protein components in periodontal ligament fibroblasts. J Periodontol 76: 1645-1653.

Rowe DJ, TOM XM, SLIVERSTEIN SJ AND RICHARDS DW. 1999. Enhanced production of mineralized nodules and collagenous proteins in vitro by calcium ascorbate supplemented with vitamin C metabolites. J Periodontol 70: 992-999.

RUSSELL RM AND SUTER M. 1993. Vitamin requirements of elderly people: an update. Am J Clin Nutr 58: 4-14.

SChOFFEN JP, SoARES A, DE Freitas P, ButTow NC AND NATALI MR. 2005. Effects of a hypoproteic diet on myosin-V immunostained myenteric neurons and the proximal colon wall of aging rats. Auton Neurosci 122: 77-83.

Senturk N, Keles GC, Kaymaz FF, Yildiz L, ACIKGOZ G AND TURANLI AY. 2004. The role of ascorbic acid on collagen structure and levels of serum interleukin-6 and tumour necrosis factor-alfa in experimental lathyrism. Clin Exp Dermatol 29: 168-175.

Telang S, Clem AL, Eaton JW And Chesney J. 2007. Depletion of Ascorbic Acid Restricts Angiogenesis and Retards Tumor Growth in a Mouse Model. Neoplasia 9: 47-56.

TSUCHIYA H AND BATES CJ. 1998. Changes in collagen crosslink ratios in bone and urine of guinea pigs fed graded dietary vitamin C: A functional index of vitamin C status. J Nutr Biochem 9: 402-407.

TUero BB. 2000. The role of vitamin $\mathrm{C}$ in the metabolism of the collagen. Rev Cubana Aliment Nutr 14: 46-54.

VAN DER PAUW MTM, VAN DEN BOS T, EVERTS V AND BEERTSEN W. 2001. Phagocytosis of fibronectin and collagens type I, III and V by human gingival and periodontal ligament fibroblasts in vitro. J Periodontol 72: 1340-1347.

WILSON JX. 2002. The physiological role of dehydroascorbic acid. FEBS Letters 527: 5-9.

Yen EHK, Yue CS AND SugA DM. 1989. Effect of force level on synthesis of type III and type I collagen in mouse interparietal suture. J Dent Res 68: 1746-1751.

Young IS, TORNEY JJ AND TRIMBLE ER. 1992. The effect of ascorbate supplementation on oxidative stress in the streptozotocin diabetic rat. Free Radic Biol Med 13: 41-46. 